\title{
Issues and Challenges In the Production of Handicrafts by Iban and Orang Ulu Women in Central Sarawak
}

\author{
Salfarina Abdul Gapor ${ }^{1}$, Haris Fadzilah Abdul Rahman ${ }^{1}$, Daniel Ugih Echoh*1 \\ and Anita Rosli ${ }^{2}$, \\ ${ }^{1}$ Department of Architecture \\ School of Built Environment \\ University College of Technology Sarawak \\ ${ }^{2}$ Department of Management \\ Faculty of Agriculture and Food Sciences \\ Universiti Putra Malaysia Bintulu Sarawak Campus \\ Corresponding author: dr.danielugih@ucts.edu.my
}

\begin{abstract}
Malaysia has made an effort to protect handicrafts under Jabatan Warisan Negara and promote small scale production under the Malaysian Handicraft Development Corporation. There is also an NGO working to promote and preserve handicrafts in Sarawak, such as the Society Atelier Sarawak. Seven of Sarawak's handicraft have been awarded the prestigious UNESCO/World Crafts Award of Excellence in 2016. However, at the grass root level amidst the efforts to promote handicraft industry in Malaysia, the scenario differs. This paper aims to identify issues and problems faced by Iban women who are involved in handicraft production in Central Sarawak. This research employs a qualitative approach through in-depth interview and participatory rural appraisal. A total of 17 longhouses were visited for the study and interviews were conducted on 34 women who were involved in handicraft production. Findings show that the main type of handicraft are mat, weaved textile (pua kumbu), beads jewelleries and accessories, baskets, bags and souvenir items like key chain. The main reasons for continuing the tradition includes interest, way of life and self-consumption and seeking for additional income.
\end{abstract}

Keywords: Central Sarawak, Handicraft, Iban, Rural development, Women

\section{Introduction}

Handicrafts have been studied under various rubrics, mainly through sociological and anthropological approach that examine the values of handicrafts to the society as cultural image and identity. On the other hand, the production of handicraft has also been studied under socioeconomic development as part of the "cottage industries" or "rural industries" (Mohamad, 1996). In rural development, apart from agricultural sectors, the cottage or rural industries can provide alternative or additional livelihoods to the rural community, especially avenues for women to gain self-determination and financial empowerment. Handicraft items are also important cultural and heritage representations of a state or a nation. Therefore, in Malaysia, many efforts have been done to protect handicrafts under the Jabatan Warisan Negara and promote small scale production by the Malaysian Handicraft Development Corporation, which is under the purview of the Ministry of Tourism, Malaysia. 
The Malaysian Handicraft Development Corporation has branches at state level, including in Sarawak. In addition to efforts done by governmental departments, NGOs also play an important role to promote the preservation and conservation of handicrafts as cultural heritage, for example in Sarawak, the Society Atelier Sarawak promotes and preserves handicrafts of Sarawak. As a result, seven of Sarawak's handicraft have been awarded the prestigious UNESCO/World Crafts Award of Excellence in 2016. However, at the grass root level amidst the efforts to promote handicraft industry in Malaysia, the scenario differs. Salfarina and Hafizah (2010) indicates clearly the decline in the number of those actively involved in handicraft production, in their case study on Terendak Igan production (the Melanau traditional sun conical hat), especially among the younger generation in Igan, Sarawak.

There are little incentives and limited avenue for them to market their products and in many cases, middle person's exploitation is also common (Salfarina \& Hafizah, 2010). Although several studies were done on handicraft and development (Eva, Neilson, \& Wong, 2017; Faridah, Anna, \& Spencer, 2016; Faridah, 2012; Madeline, 2001) this paper differs as its focuses on collecting benchmarking database of handicraft producers in Central Sarawak, which areas have been identified as future eco-tourism sites under the Sarawak Corridor of Renewable Energy (SCORE) regional development. The objective of this paper are thus, to identify motives, issues and problems faced by the Iban and Orang Ulu women who are involved in handicraft production in Central Sarawak.

\section{Literature Review}

The rural communities in Sarawak remain dependent on the availability of natural resources as they utilize the natural resources for their livelihoods such as agriculture, forest plantation, hunting, fishing, logging and handicraft making. Handicraft making is one of the rural community's activities that depend heavily on the availability of natural resources as main raw material. Thus, any changes or degradation in the environment, such as clearance of forest for development purposes will affect and change their livelihood. The production of handicraft is not only for family and personal use, but it can also be one of the sources of income. According to Madeline (2001), for the rural people of Sarawak, involvement in commercial handicraft production provides them with the opportunity to earn cash income and participate in part-time employment, especially for the disadvantaged groups such as the poorly educated, women and the elderly in rural Sarawak.

However, handicraft production faces several challenges, such as, scarcity of raw material. The twin forces of raw material depletion and changing value (in taste/fashion/demand for these indigenous utilitarian objects) threaten the continued manufacture of these objects. The current situation suggests that their manufactured items as utilitarian objects would cease and be replaced by industrially manufactured consumer products fulfilling modern household needs. What remains of the once rich indigenous material assemblage would be the commoditized production of some such objects as crafts for the tourism industry. Even in the production of commoditized crafts would be dictated by the scarcity of traditional raw material, global taste and demand, and the availability of synthetic materials (Faridah, 2012).

A study was conducted by Faridah, Anna, and Spencer (2016) among the Org Ulu (Kayan, Kenyah, Badeng, Bhukat, and Penan) in the Sungai Asap Resettlement scheme of Belaga, Sarawak found that the changing physical landscape due to development projects in the region has caused a scarcity of construction materials, both in quantity and diversity. These factors affect the traditional craft-making activities and have become the main challenge for the 
Orang Ulu craft makers to sustain their tradition and heritage. Thus, there are three strategies to sustain traditional handicraft such as, reproduction of traditional product (using alternative raw material), innovation of traditional product, and participation of youth in craft-making. Besides, the knowledge and skills in craft-making among young generations, including women are eroding due to less interest to participate in traditional handicraft production. Eva, Neilson, and Wong (2017) found that the knowledge on the types and availability of resources in the respective areas, as well as the gap of knowledge in resource use and management between the older and younger generations and the scarcity of raw materials such as rattan and wood has resulted in the decline of handicrafts production.

\section{Methodology}

This research employs a qualitative approach through in-depth interview and participatory rural appraisal. A total of 17 longhouses were visited for the study and interviews were conducted on 34 women who were involved in handicraft production. The study are focused at longhouses in Central Sarawak in the districts of Kapit, Song, Kanowit and Belaga. Selection of the longhouses are chosen using quota sampling based on districts and also based on suggestions from Kapit Resident Office, as well as taking into account the distance of the longhouses from the rural centres. The rural centres are Kapit, Song, Kanowit, Belaga, and Sungai Asap (refer to Figure 1 and Table 1).

Table 1: Study Area based on District

\begin{tabular}{|c|c|c|c|c|}
\hline District & Longhouse & Frequency & Percent & $\begin{array}{c}\text { Distance } \\
\text { from Rural } \\
\text { Centre }(\mathrm{Km})\end{array}$ \\
\hline \multirow{5}{*}{ Kapit } & Rh Ikau & \multirow{5}{*}{5} & \multirow{5}{*}{29.4} & 10 \\
\hline & Rh Emperan Pisang & & & 24 \\
\hline & Rh Enting & & & 13 \\
\hline & Rh Manuk Mancal & & & 18 \\
\hline & Rh Richard Engking & & & 5 \\
\hline \multirow{3}{*}{ Song } & Rh Jarop & \multirow{3}{*}{3} & \multirow{3}{*}{17.6} & 5 \\
\hline & Rh SERIT & & & 15 \\
\hline & Rh Timothy & & & 6 \\
\hline \multirow{3}{*}{ Kanowit } & Rh Alexander Luntang & & \multirow{3}{*}{17.6} & 8 \\
\hline & Rh Gerut & & & 8 \\
\hline & Rh Arun & 3 & & 10 \\
\hline \multirow{6}{*}{ Belaga } & Rh Bawan & \multirow{6}{*}{6} & \multirow{6}{*}{35.3} & 12 \\
\hline & Rh Daro & & & 6 \\
\hline & Rh Lahanan & & & 3 \\
\hline & Rh Nyaving & & & 25 \\
\hline & Rh Ukit & & & 12 \\
\hline & $\begin{array}{l}\text { Uma Penang, Belangan, Sg. } \\
\text { Asap }\end{array}$ & & & 12 \\
\hline
\end{tabular}




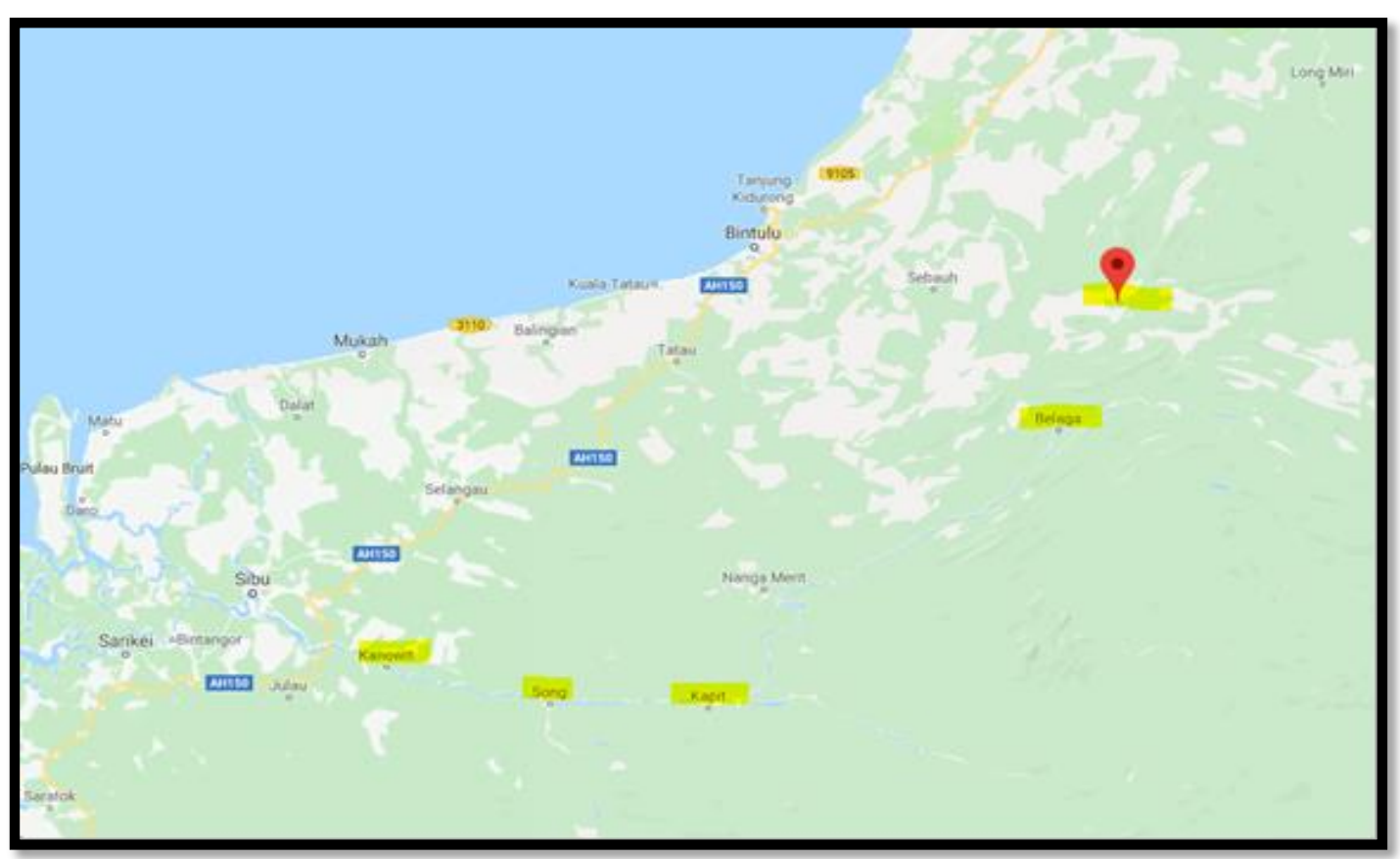

Figure 1 Study Areas in Central Sarawak

Source: https://www.google.com/maps/place

Data analysis is done using content analysis by coding the findings into demographic profiling, themes, i.e., types of handicrafts produced, reasons for pursuing handicraft production, marketing strategies (if any), and challenges and opportunities in upholding handicraft production as part of their identity and cultural heritage.

\section{Findings \& Discussion}

Interview on handicraft production is part of the overall socio-economic and environmental study in rural areas of Central Sarawak. 17 longhouses were chosen based on quota sampling and consultation with the Kapit Resident Office. Out of the 17 longhouses, 3 longhouses are no longer participating in the handicraft production, these are $\mathrm{Rh}$ Enting, $\mathrm{Rh}$ Arun, and $\mathrm{Rh}$ Lahanan, Long Semuan. 14 longhouses are still producing handicraft and the most active ones are in Song at Rumah Jarop, Nanga Sepadi and Rh Serit, and Rh Manuk Mancal in Kapit (refer to Table 2). Rh Jarop, Nanga Sepadi was built in 1983 to replace the old long house at Nanga Ririk, which is about 3 kilometres away from the current location in Song. Rh Jarop, Nanga Sepadi pride itself as the longhouse of Balang, the Iban warrior. The community built Balang statue and still keep his machete and plates as a reminder of the warrior. There have 20 women who are active in handicraft production. 
Borneo Journal of Social Science \& Humanities

DOI: https://doi.org/10.35370/bjssh.2019.1.2-10

e-ISSN: 2682-8235

(C) 2018, UCTS Publisher.

Submitted: 12 September 2019

Accepted: 1 December 2019

Published: 31 December 2019

Table 2: Number of longhouse members involved in handicraft production

\begin{tabular}{|c|c|c|c|c|}
\hline District & Longhouse & $\begin{array}{l}\text { Involved in } \\
\text { handicraft }\end{array}$ & $\begin{array}{l}\text { Number of longhouse } \\
\text { member involved in } \\
\text { handicraft production }\end{array}$ & $\begin{array}{c}\text { Respondents } \\
\text { (n) }\end{array}$ \\
\hline \multirow[t]{5}{*}{ Kapit } & Rh Ikau & $\sqrt{ }$ & 3 & 1 \\
\hline & Rh Emperan Pisang & $\sqrt{ }$ & 4 & 1 \\
\hline & Eh Enting & $\sqrt{ }$ & 0 & 0 \\
\hline & Rh Manuk Mancal & $\sqrt{ }$ & 7 & 5 \\
\hline & Rh Richard Engking & $\sqrt{ }$ & 5 & 3 \\
\hline \multirow[t]{3}{*}{ Song } & Rh Jarop & $\sqrt{ }$ & 20 & 8 \\
\hline & Rh Serit & $\sqrt{ }$ & 10 & 8 \\
\hline & Rh Timothy & $\sqrt{ }$ & 3 & 1 \\
\hline \multirow[t]{3}{*}{ Kanowit } & Rh Alexander & $\sqrt{ }$ & 3 & 1 \\
\hline & Rh Gerut & $\sqrt{ }$ & 4 & 1 \\
\hline & Rh Asun & $x$ & 0 & 0 \\
\hline \multirow[t]{6}{*}{ Belaga } & Rh Bawan & $\sqrt{ }$ & 4 & 1 \\
\hline & $\mathrm{Rh}$ Daro & $\sqrt{ }$ & 5 & 1 \\
\hline & Rh Lahanan & $x$ & 0 & 0 \\
\hline & Rh Nyaving & $\sqrt{ }$ & 4 & 1 \\
\hline & Rh Ukit & $\sqrt{ }$ & 3 & 1 \\
\hline & Uma Penan & $\sqrt{ }$ & 5 & 1 \\
\hline Total $(\mathrm{N})$ & & & 80 & 34 \\
\hline
\end{tabular}

Source: Author

The dwellers of Rh Serit, Song moved four times to escape floods and communist insurgency in the 70s and 80s. The existing longhouse was completed in 2013. The earliest longhouse was built in the 1940s in the headwaters of Sungai Takan. The longhouse is involved with the Department of Agriculture's (DOA) "Tagang System" project. Tagal system is a formal community property resource management, whereby the community acted as river keepers, who are involve directly in the resource management of endemic fish (semah and tengadak) in the area. This is the second most active handicraft producers, with 10 producers. Rh Manuk Manchal is located in Kapit district and the dwellers also experiences moving of their longhouses. The original longhouse was built in 1850 in the interior of Ulu Yong, the movement is caused by the lack of timber to repair the old longhouses, movement nearer to road instead of river and embracing brick and mortar as new building materials. This is the most active handicraft producers in Kapit and has won Kampung Bestari award for well-planned and cleanliness criteria.

From the 14 longhouses, 80 women are still producing handicrafts. Those involved are all women, from the initial stage of collecting or buying raw materials, processing until the marketing stages. Marital status of the respondents varies, most are married, smaller percentage are widows but among the married, higher percentage are "single parent" because their husbands are working elsewhere, some work as far Solomon Islands, Papua New Guinea and even as far as Dubai. There are unmarried younger women joining the "handicraft group production", mainly as apprenticeship. The operational cost are mainly borne by the older married woman, who is also perceived informally as the group leader. In terms of education background, 47 percent do not have any formal education, 29 percent primary school level, 18 percent with secondary school and only 6 percent with higher level of education at Diploma level. In terms of age, majority are between mid-50s to 70 years old. 
There are less percentage between 30 to late 40s and very few younger generations, who merely come to help now and then or just observe the production. Seasonal calendar of craft production shows a very distinct trend. Handicraft production stops in January because they focus on preparation to celebrate New Year and selling indigenous fruits (durian, dabai, engkalak, rambutan, terap, kristal (kasai), Sarawak longan and keranji). The handicraft production continues from February to May and stop for Gawai festival celebration in June. June is also the time for wedding and rice harvesting. The production continues again in August and ends in October. In November until December, the women are busy with fruit harvesting and selling of indigenous fruits, which contributed rather substantially to their household income.

The main indigenous raw materials for handicraft production are rattan (Calamus), bamboo (bambusa vulgaris), bemban (Donax canniformis), palm leaves and cotton yarn. Artificial materials mainly used are plastic packaging strip (PPS), which cost between RM 50 -70 per roll. The PPS are used to weave baskets, bags and mats. There are less comfortable as mats but most respondents have no choice due to difficulty in accessing natural indigenous raw materials due to deforestation and movement of longhouses nearer to roads and rural centres. Age of the respondents also contributes to inaccessibility to the natural raw materials because most of the materials are available in their old longhouse, up rivers in the interior. It may take about two to three days to enter the jungles with rattan, bamboo and bemban. PPS is favoured because of accessibility, price and less processing work compared to the natural materials. Types of handicrafts produced are mat, weaved textile (pua kumbu), beads jewelleries and accessories, baskets, bags, sun conical hats and souvenir items like key chain (Please refer to Table 3).

Table 3: Longhouses and their Handicraft Products

\begin{tabular}{|c|c|c|c|}
\hline District & Longhouse & Types of handicraft Produced & Product Samples \\
\hline & Rh Ikau & Rattan basket and mat & \\
\hline \multirow{2}{*}{ Kapit } & $\begin{array}{c}\text { Rh Emperan } \\
\text { Pisang }\end{array}$ & Plastic baskets and bags & \\
\hline & $\begin{array}{l}\text { Rh Manuk } \\
\text { Mancal }\end{array}$ & $\begin{array}{c}\text { Rattan mat, plastic basket, } \\
\text { Plastic bag, beads }\end{array}$ & \\
\hline
\end{tabular}


Borneo Journal of Social Science \& Humanities

DOI: https://doi.org/10.35370/bjssh.2019.1.2-10

e-ISSN: 2682-8235

(C) 2018, UCTS Publisher.

Submitted: 12 September 2019

Accepted: 1 December 2019

Published: 31 December 2019

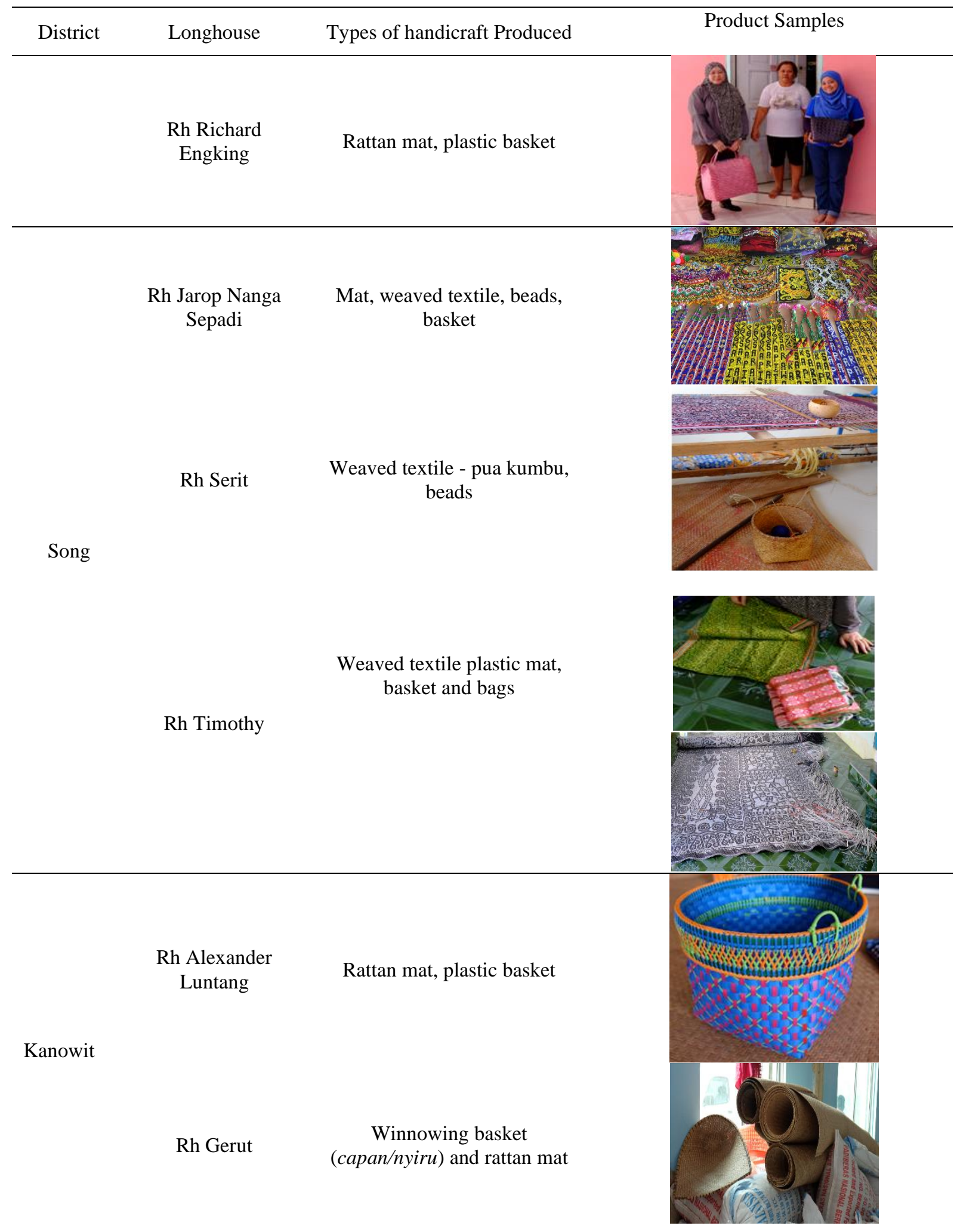


Borneo Journal of Social Science \& Humanities

DOI: https://doi.org/10.35370/bjssh.2019.1.2-10

e-ISSN: 2682-8235

(C) 2018, UCTS Publisher.

Submitted: 12 September 2019

Accepted: 1 December 2019

Published: 31 December 2019

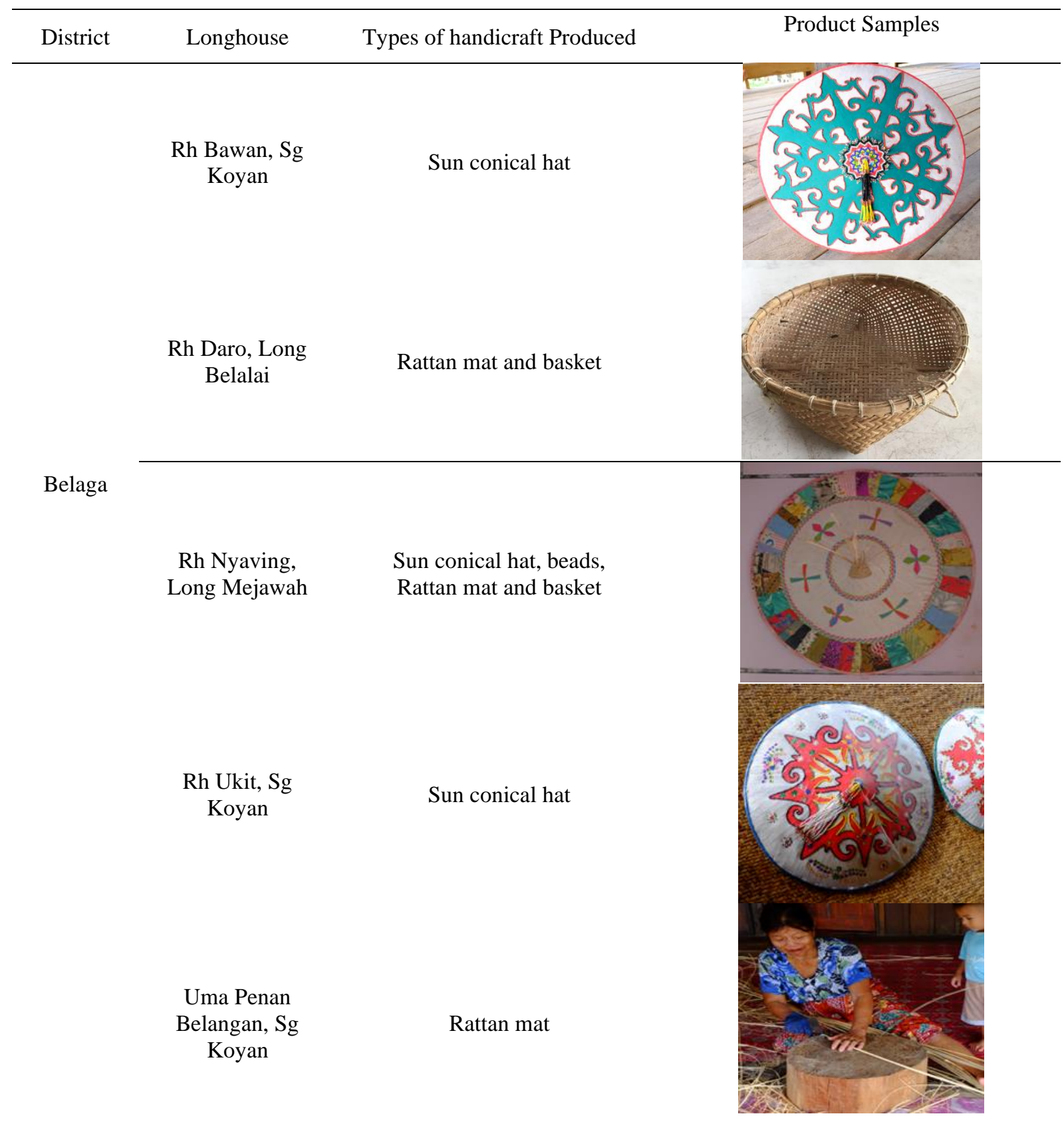

Source: Authors

The main reasons for continuing the tradition includes interest, way of life and selfconsumption, seeking for additional income, to kill time and upholding handicraft production as part of their identity and cultural heritage.

Table 4: Reasons for pursuing handicraft production, challenges, and marketing strategies

\begin{tabular}{|c|c|c|c|c|}
\hline District & Longhouse & $\begin{array}{l}\text { Reasons for pursuing } \\
\text { handicraft production }\end{array}$ & $\begin{array}{l}\text { Challenges to sustain } \\
\text { handicraft production }\end{array}$ & $\begin{array}{l}\text { Marketing } \\
\text { strategies }\end{array}$ \\
\hline
\end{tabular}


Borneo Journal of Social Science \& Humanities

DOI: https://doi.org/10.35370/bjssh.2019.1.2-10

e-ISSN: 2682-8235

(C) 2018, UCTS Publisher.

Submitted: 12 September 2019

Accepted: 1 December 2019

Published: 31 December 2019

\begin{tabular}{|c|c|c|c|c|}
\hline \multirow[t]{4}{*}{ Kapit } & Rh Ikau & $\begin{array}{l}\text { Interest and better than just } \\
\text { sitting around doing nothing }\end{array}$ & $\begin{array}{l}\text { Marketing, younger } \\
\text { generation not interested } \\
\text { to continue tradition }\end{array}$ & No strategy \\
\hline & $\begin{array}{l}\text { Rh Emperan } \\
\text { Pisang }\end{array}$ & Spare time activities & $\begin{array}{l}\text { Access to natural raw } \\
\text { materials }\end{array}$ & No strategy \\
\hline & $\begin{array}{l}\text { Rh Manuk } \\
\text { Mancal }\end{array}$ & $\begin{array}{l}\text { Additional Income, interest, } \\
\text { identity and cultural heritage }\end{array}$ & $\begin{array}{l}\text { Access to natural raw } \\
\text { materials }\end{array}$ & $\begin{array}{l}\text { Tourist and } \\
\text { visitors }\end{array}$ \\
\hline & $\begin{array}{l}\text { Rh Richard } \\
\text { Engking }\end{array}$ & Additional Income & $\begin{array}{l}\text { Access to natural raw } \\
\text { materials }\end{array}$ & Tourist visiting \\
\hline \multirow[t]{3}{*}{ Song } & Rh Jarop & $\begin{array}{l}\text { Additional Income, interest, } \\
\text { identity and cultural heritage }\end{array}$ & $\begin{array}{l}\text { Access to natural raw } \\
\text { materials }\end{array}$ & $\begin{array}{l}\text { Through family } \\
\text { members at } \\
\text { Sibu Jaya }\end{array}$ \\
\hline & Rh Serit & $\begin{array}{l}\text { Additional Income, interest, } \\
\text { identity and cultural heritage }\end{array}$ & $\begin{array}{l}\text { Access to natural raw } \\
\text { materials }\end{array}$ & Visitors \\
\hline & Rh Timothy & $\begin{array}{l}\text { Additional Income, interest, } \\
\text { identity and cultural heritage }\end{array}$ & $\begin{array}{l}\text { Access to natural raw } \\
\text { materials }\end{array}$ & No strategy \\
\hline \multirow[t]{2}{*}{ Kanowit } & Rh Alexander & $\begin{array}{l}\text { Way of life and self- } \\
\text { consumption }\end{array}$ & No stable demand & No strategy \\
\hline & Rh Gerut & $\begin{array}{l}\text { Way of life and self- } \\
\text { consumption }\end{array}$ & Marketing & No strategy \\
\hline \multirow[t]{2}{*}{ Belaga } & Rh Bawan & Additional income & $\begin{array}{l}\text { Access to natural raw } \\
\text { materials }\end{array}$ & Visitors \\
\hline & Rh Daro & $\begin{array}{l}\text { Way of life and self- } \\
\text { consumption, identity and } \\
\text { cultural heritage }\end{array}$ & Marketing & No strategy \\
\hline \multirow[t]{3}{*}{ Sg. Asap } & Rh Nyaving & $\begin{array}{l}\text { Way of life and self- } \\
\text { consumption, identity and } \\
\text { cultural heritage }\end{array}$ & Marketing & No strategy \\
\hline & Rh Ukit & Additional income & $\begin{array}{l}\text { Access to natural raw } \\
\text { materials }\end{array}$ & Visitors \\
\hline & Uma Penan & Additional income & $\begin{array}{l}\text { Access to natural raw } \\
\text { materials }\end{array}$ & Visitors \\
\hline
\end{tabular}

Source: Author

Majority of the handicraft producers do not have specific marketing strategy, some are just waiting for tourists and visitors to buy their products to exchange for cash. Rh Jarop, Nanga Sepadi happened to have relatives and friends who have moved to Sibu Jaya, as a good platform to market their products. Being the longhouse with the most active members in handicraft production, a stable demand with certainty encourages the producers to invest more on the raw materials and provide incentives for more women in the longhouse to actively participate in handicraft production. The main challenges are related to difficulty to get raw natural materials such as rattan for the handicrafts, no proper platform to market the products and lack of interest by the younger generation to continue the tradition. 


\section{Conclusion}

In the light and scale of deforestation in Sarawak, there is no point in putting efforts to increase accessibility by planting more rattan, bamboo or bemban in a large scale. In a control environment, this might be successful but not as a plantation, due to the nature of ecosystem that the natural plants need for healthy and continuous natural propagation. Hence, it is better to use science and technology through wood processing technique to produce raw materials, which mimic the PPS flexibility but using waste from biodegradable sources like oil palm fruit bunch or saw dust as alternative to the unsustainable PPS. A more localised and participatory project at micro level involving all grassroot stakeholders should be organised to sustain this culture in Central Sarawak apart from continuing the agenda of effective marketing, such as through socio media and ecommerce, and internal resource generation through both formal and informal

\section{Acknowledgements}

The authors would like to thank UCTS for funding the research under the UCTS Research Grant.

\section{Reference}

Madeline, B. (2011). Alternative development and the role of commercial handicraft production in Sarawak, Malaysia. Akademika, 59, 33-51.

Mohamad, M. (1996). The Malay handloom weavers: a study of the rise and decline of traditional manufacture, ISEAS: Singapore.

Faridah, S., Anna, D., \& Spencer, E.S. (2016). Cabaran dan peranan pembuat kraf dalam pelestarian budaya benda masyarakat Orang Ulu di Belaga Sarawak [Craftmakers' challenges and roles in sustaining material culture among the Orang Ulu in Belaga Sarawak]. Borneo Research Journal, 10, 111-126.

Eva, K.L.S., Neilson, I.M., \& Wong, S.K. (2017). Traditional handicrafts and the use of natural resources among the Iban of Balai Ringin, Serian. Journal of Borneo Kalimantan Abstract, 3(2), 58.

Faridah, S. (2012). Sustainability of Orang Ulu Traditional Craft. Presented in Research Innovation for Malaysian Peninsula, Borneo and Australia (RIMBA), Sarawak, Institute of Biodiversity and Environment Conservation.

Salfarina Abdul Gapor. \& Hafizah Selamat (2010). The Process Linkages in the Marketing of Terendak igan for Tourism in Sarawak. World Applied Sciences Journal, 10, 121-125. 
Borneo Journal of Social Science and Humanities

DOI:

e-ISSN:

(C) 2018, UCTS Publisher.

Submitted:

Accepted:

Published: 